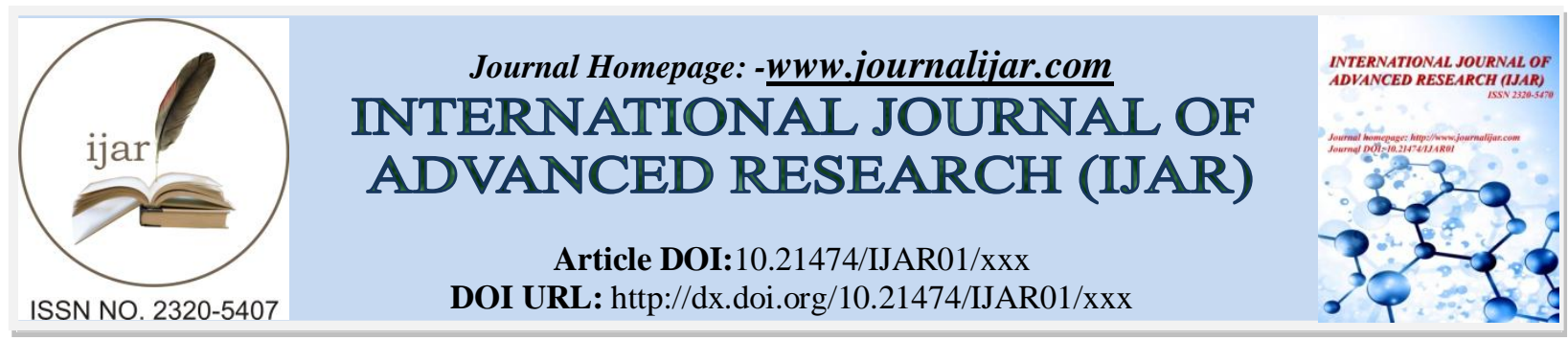

RESEARCH ARTICLE

\title{
THE REALISTIC VIEW OF CONTRACT LABOUR(REGULATION\& ABOLITION) ACT, 1970.
}

Dr. Shweta Sethi ${ }^{1}$ and Mr. Neeraj Kataria ${ }^{2}$.

1. Associate Professor, Swami Rama Himalayan University, Jolly Grant, Dehradun India.

2. Assistant Professor, Department of Management Studies, University of Petroleum \& Energy Studies, Dehradun, India.

\section{Manuscript Info}

Manuscript History

Received: 18 October 2016

Final Accepted: 20 November 2016

Published: December 2016

\section{Abstract}

The Indian labour law regime faces the problem of plenty. In India, a number of labor legislations have been enacted to promote the condition of labor keeping in view the development of industry and national economy. Especially after opening the economy in the early nineties and globalization, the industrial picture of India has changed completely. Adoption of high-tech methods for the production and the quality of the products has assumed an exceptional importance. Output and profitability have assumed greater importance, encouraging some employers to bypass the laws enacted for protection of the interests of the workers. One of such laws which was passed for the protection of the contract labour was the Act, Contract Labour (Regulation and Abolition) (CLRA) 1970. In the present study an attempt has been made to have an insight whether any improvement or changes have occurred in the working conditions of the contract labour after the implementation of the Act. The study also aims to find out whether the aforesaid act has been successful in meeting its purpose.

Copy Right, IJAR, 2016,. All rights reserved.

\section{Introduction:-}

According to National Sample Survey Organization (NSSO), approximately 400 million people in India are employed in the unorganized sector that is near to $92 \%$ of total workforce. This is the largest population of unsecured workers on earth only after China, where the clear figure is still unknown. Majority of the people are employed in agriculture, small shops, construction, and manufacturing sectors. These workers work without any authentic Social Security measures that the workers in the organized sector get. However Social Securities Act for unorganized sector was enacted by The Parliament in 2008, which provides for social security to unorganized workers through various central government schemes. The employability and wages of these workers is subject to demand and supply forces in the labour market. These workers are largely unskilled / semi-skilled. With meager income levels they can hardly afford nutrition, education and healthcare, which form the basis of economic development of a nation. With stringent labor laws hiring and firing becomes difficult thus providing an economic reason to employers to opt for contract workers. To cope with temporary surge in demand of unskilled and semiskilled manpower, companies in Government and Private sector employ contract labor.

Contract worker is an employee who is employed by the "Principal Employer", indirectly through a "contractor". The contract of employment is between the employee and the contractor. The employee actually works for the 
"Principal Employer". For Full time employees there is only one contract - between the employer, and the candidate. For contract labor employment there are two contracts:

1. Contract of employment between contract worker and contractor.

2. Obligation to work between contract worker and Principal employer.

A workman is deemed to be employed as Contract Labour when he is hired in connection with the work of an establishment by or through a Contractor. Contract workmen are indirect employees. Contract Labour differs from Direct Labour in terms of employment relationship with the establishment and method of wage payment. Contract Labour, by and large is not borne on pay roll nor is paid directly. The Contract Workmen are hired, supervised and remunerated by the Contractor, who in turn, is remunerated by the Establishment hiring the services of the Contractor. Contract labours suffer from inferior labour status, casual nature of employment, lack of job security and poor economic conditions. It was also observed that in some cases the contract labourers did the same work as the workers directly employed by the industrialist but were not paid the same wages and the same working conditions. This practice of contract labour has also lead to the exploitation of these laborers as they are not employed directly under the employer.

The Contract Labour Act was passed to prevent exploitation of contract labour and also to introduce better conditions of work. The Act provides for regulation and abolition of contract labour. The underlined policy of the Act is to abolish contract labour wherever possible and practicable and where it can be abolished altogether, the working conditions of the contract labour should be so regulated as to ensure payment of wages and provisions of essential amenities. The Act provides for regulated conditions of work and contemplates progressive abolition to the extent contemplated under the Act. It extends to the whole of India and applies to:

1. Every establishment in which twenty or more persons are employed or were employed on any day of the preceding twelve months as contract labour .

2. To every contractor who employs or who employed on any day of the preceding twelve months twenty or more workmen.

The appropriate government can extend the provisions of the Act to any establishments or contractor employing less than the number specified above, by notification. It shall not apply to establishments in which work is of intermittent or casual nature. The act does not apply:

a) To establishments in which work only of an intermittent or casual nature is performed.

b) If a question arises whether work performed in an establishment is of an intermittent or casual nature, the appropriate Government shall decide that question after consultation with the Central Board or, as the case may be, a State Board, and its decision shall be final.

Contract Labour Compliances is one of the most important areas and a lot of research has been done so far on it. The literatures indicate the condition of contract labour and the role this Act plays. (RamchandaniDhiraj, 2006) The practice of employing contract labour is prevalent in most of the industries in different occupation including skilled and semi-skilled jobs. A workman shall be deemed to be employed as contract labour when he is hired in connection with the work of an establishment by or through a contractor. The various studies conducted by commissions, committees and Ministry of Labour shows that the situation has always been exploitative. The government has taken various initiatives to improve the situation of the contract.

(Meenakshi Rajeev, 2009) A primary survey carried out in Karnataka, an industrially developed state, reveals that many of the stipulations made in the Act to safeguard contract labour are not followed in practice. It has been felt by the workers that collusive agreement between the Labour Inspector, the protector of law, and the principal employer and the contractor has aided the violation of law. Among different kinds of employment that have been created in various economies to circumvent labour laws, contract labour is becoming one of the prominent forms. It is revealed through survey that some of the companies maintain more than one register, one for the scrutiny of the labour inspector and other contains the actual figures.

India's economic success is not improving the lives of contract and informal workers who form the largest section of the economy and make a major contribution to the country's global success.(MaitiDibyendu, 2009) In India we observe an increasing use of casual, contract or other such non regular labour over a time-period. In India's manufacturing sector surprisingly high levels of contract workers are being used, in some cases, as many as three times the regular workers. The official estimate however, states that, some of India's key industries such as cement, 
iron and steel, cotton textile and jute, rely on contract labour. As many as four out of every five workers are contract workers. The official record of industrial statistics puts the share of contract labour in organised manufacturing sector at $15 \%$ to $26 \%$ across West Bengal and Gujarat states; but research found the share to be much higher, up to $60 \%$ to $70 \%$ across these states.(Upadhyaya Sanjay, 2009) Process of globalization, liberalization has resulted in the increase in the trend towards substitution of regular employment by contract employment and this trend is going to continue and grow in future. One of the major factors responsible for preferring contract labour against the regular employees is the temptation to lower overall wage cost for similar quality and quantity of work.

Many of the benefits, even the statutory ones, like provident fund, sickness insurance, gratuity, and privilege leave with pay and so on are usually not available to contract workers.Indian state has made different enactments for labour at different points of time to cover various categories of workers including contract labour. However the limitations and constraints of most of these enactments are that majority of these enactments put one kind of ceiling or the other either in terms of number of workers engaged or wages or duration of employment for the purpose of coverage under these enactments. As a result large section of vulnerable group of workers including those working as contract labour is left out of the legislative coverage and protection. Another limitation of these legislative measures is that the various kinds of penalties provided under most of these enactments are quite meagre in nature and the procedures prescribed under most of these enactments for realizing various kinds of dues and benefits are quite cumbersome which defeats the very purpose of making elaborate legislative provisions.

(Saini Debi, 2010) The rights conferred on the contract workers by the Constitution of India and various labour laws are poorly enforced. Since May 2007 the Indian Government has been talking to the need for inclusive growth mainly to counter act the above threats envisaged by the social scientists. It should be kept in mind that inclusive growth can be sustained only if it is built on the foundations of basic rights of the working people, especially the powerless people. The Contract Labour( Abolition \& Regulation) Act , 1970 was passed for the protection of contract labour.

\section{Objectives of the study:-}

In the present study an attempt has been made to have an insight whether any improvement or changes have occurred in the working conditions of the contract labour after the implementation of the Act. The study also aims to find out whether the aforesaid act has been successful in meeting its purpose. Thus keeping the focus on this main objective, following sub areas were studied during the study:

* To evaluate the working condition of the contract workers in the context of the Act by finding out the facilities available to them at their work places.

* To understand the mechanism and methodology of the implementation of the Act.

* To examine the role of contractor in the effective implementation of the Act.

* To consider the utility of the Act and also suggest the improvements required to be made in the Act.

\section{Scope of the study:-}

The study covered the industrial zone SIDCUL (State Industrial Development Corporation of Uttarakhand Limited), Haridwar, Uttarakhand.. A few industrial establishments have been included in this study where a good proportion of contract labour is employed.Thus this study is restricted to the workers appointed as contract workers and for whom the Act is applicable.

\section{Sampling Universe:-}

Sampling universe for this study was the contract labours in industrial establishments of SIDCUL.

\section{Sample Size:-}

It included 50 contract labours of the defined area of study and 2 contractors.

\section{Method of Data Collection:-}

In the study most of the data is collected through primary source. The interview schedules were prepared to obtain the responses of contract labour. Also, to complement theinterview schedules, Focused Group Discussions (FGDs) were conducted with a few contractors and key persons of industrial undertaking in order to understand their perspectives. 


\section{Data Analysis:-}

Field research was carried out as mentioned earlier. The analysis of the relevant data gathered during the survey has been presented with the help of thefollowing tables.

\section{Personal Information of the contract workers Selected for the Survey:-}

The detailed information of the contract workers selected for the survey viz. their age group, level of education, marital status and family background has been collected during this survey for understanding their background.

Age Group:-

Out of 50 contract workers surveyed, more than half i.e. $51.8 \%$ were found to be in the age group of 26 to 35 years, while $26 \%$ were of the age less than 25 years of age.

\begin{tabular}{|c|c|c|}
\hline Age Group & Number & \% \\
\hline $18-25$ & 30 & 60 \\
\hline $26-35$ & 14 & 28 \\
\hline $36-50$ & 06 & 12 \\
\hline $51-60$ & 0 & 0 \\
\hline Total & 50 & 100 \\
\hline
\end{tabular}

Out of 50 contract workers surveyed, more than half i.e. $60 \%$ were found to be in the age group of 26 to 35 years, while $28 \%$ were of the age less than 25 years of age. In short, more than three fourth of them belong to a young age group. The youth have greater physical strength and therefore those establishments gave preference for employing this category of the workers.

Educational level:-

\begin{tabular}{|c|c|c|}
\hline Education & Number & \% \\
\hline Illiterate & 02 & 4 \\
\hline Primary (Up to 7th) & 12 & 24 \\
\hline Up to 10th & 17 & 34 \\
\hline Up to 12th & 14 & 28 \\
\hline Graduate & 0 & 0 \\
\hline ITI Trained & 05 & 10 \\
\hline Engineering Diploma & 0 & 0 \\
\hline Engineering Graduate & 0 & 0 \\
\hline Total & 50 & 100 \\
\hline
\end{tabular}

There were only two illiterate contract workers among those surveyed. About $24 \%$ of them had however, completed only Primary Level education i.e. up to 7th standard, while 34\% contract workers had studied up to 10th standard. Percentage of the contract workers who have studied up to 12th standard works out to $14 \%$. Almost $10 \%$ of contract workers were observed to have been trained in technical subjects/crafts in the Industrial Training Institutes (ITIs). This is a small percentage since majority of ITI's prefer for a secured job rather.

No of Dependents:-

\begin{tabular}{|c|c|c|}
\hline No of Dependants & Number & \% \\
\hline Nil & 0 & 0 \\
\hline One & 2 & 4 \\
\hline Two & 4 & 8 \\
\hline Three & 18 & 36 \\
\hline Four to Six & 23 & 46 \\
\hline Seven or Above & 3 & 6 \\
\hline Total & 50 & 100 \\
\hline
\end{tabular}

Average number of dependents on $46 \%$ of those contract workers was found to be 4 to 6 , while that in case of $36 \%$ of them was 3 , which indicates the significant numberof dependents on the contract workers. 


\section{Nature of Contract Work:-}

During this survey, the labourers were asked to state as to how long they were carryingout that type of work, in how many companies they had worked so far, with how manycontractors they had worked and what type of work they had carried out.

Periods of Work:-

\begin{tabular}{|c|c|c|}
\hline Period of Work & Number & \% \\
\hline Less than 1 year & 6 & 12 \\
\hline 1 to 3 years & 16 & 32 \\
\hline 3.1 to 5 yrs. & 22 & 44 \\
\hline 5.1 to 10 yrs. & 6 & 12 \\
\hline More than 10 yrs. & 0 & 0 \\
\hline Total & 50 & 100 \\
\hline
\end{tabular}

Out of 50 contract workers surveyed nearly $44 \%$ are engaged in contract work forlast 3 to 5 years. About $32 \%$ of these workers have been working as such for 1 to 3 years as contract labour.It was found that contract workers have continued working for more than five years also, with the sole hope that sooner or later they will be absorbed by the company as permanent workers. It was also reported by the contract labour that principal employers often preferred same set of workers without confirming or absorbing them. Thus in majority of cases they have encouraged new contractors to take old contract workers and seek benefits of their continued service.

Change in establishments:-

\begin{tabular}{|c|c|c|}
\hline No of Companies & Number & \% \\
\hline One & 16 & 32 \\
\hline Two & 25 & 50 \\
\hline Three & 5 & 10 \\
\hline Four or more & 4 & 8 \\
\hline Total & 50 & 100 \\
\hline
\end{tabular}

I can be seen from the above table that majority of contract workers had worked in one or two companies and their percentage works out to $82 \%$. One can clearly conclude that in spite of the fact the nature of work carried out is of permanent character, the labour force employed continues to be temporary. This is done only with a view to deprive the contract workers from claiming the benefits of a permanent worker from the principal employer.

Change of Contractors:-

\begin{tabular}{|c|c|c|}
\hline No. of Yrs. working with this Contractor & Number & \% \\
\hline Up to One Year & 12 & 24 \\
\hline 1 to 3 Years & 24 & 48 \\
\hline 3 to 5 Years & 14 & 28 \\
\hline More than 5 Years & 0 & 0 \\
\hline Total & 50 & 100 \\
\hline
\end{tabular}

The proportion of the contract workers working with the same contractor is found out to be much less over a period of time. While nearly $72 \%$ of those surveyed have worked with the same contractors for periods less than 3 years, only $28 \%$ worked beyond that. The exploitation done by the contractors is the main reason for reluctance on the part of the workers to work with the same contractor for longer periods.

Nature of Contract work:-

\begin{tabular}{|l|c|c|}
\hline \multicolumn{1}{|c|}{ Nature of Work } & Number & \% \\
\hline Supervisor & 0 & 0 \\
\hline Clerical & 0 & 0 \\
\hline Unskilled & 16 & 32 \\
\hline Semi-skilled & 10 & 20 \\
\hline Skilled & 24 & 48 \\
\hline Other & 0 & 0 \\
\hline Total & 50 & 100 \\
\hline
\end{tabular}


The contract workers covered under the survey were of unskilled, semi-skilled and skilled nature. We didn't have access to those contract workers who may be working in clerical/supervisory capacity, though it is a common knowledge that this is a growing trend.Out of 50 contract workers surveyed about $70 \%$ of them are found to be deployed in such core activities related to manufacturing/production. It is revealed from the discussions with these contract workers that, more than $70 \%$ of such activities/processes related to production are being done by those contract workers. When the managing officer of these establishments was asked about this situation, they flatly denied the employment of any contract labour in the core manufacturing processes of the establishments. This clearly shows that there is a tendency on the part of the owners of these establishments/factories, to pay low wages and extract more work from these contract workers.

Facilities/Services Made Available to the ContractLabour at the Places of Work:-

The following table gives the details of the facilities or services made available to the contract labour at their places of work.

\begin{tabular}{|c|c|c|}
\hline Facility & Number & \% \\
\hline Appointment Letter & 0 & 72 \\
\hline I Card & 36 & 60 \\
\hline Salary Slip & 30 & 90 \\
\hline PF & 45 & 100 \\
\hline ESI & 45 & 16 \\
\hline Overtime & 50 & 100 \\
\hline Weekly off & 08 & 24 \\
\hline Safety Gadgets & 50 & 100 \\
\hline Canteen & 12 & 20 \\
\hline First Aid Kit & 50 & 16 \\
\hline Rest Rooms & 10 & $\mathbf{1 0 0}$ \\
\hline
\end{tabular}

The proportion of the services like letters of appointments, paid holidays/leaves, canteens and rest rooms in case of these contract workers is quite insignificant. It was found that $72 \%$ of these contract workers are issued identity cards. This is because these identity cards are used mainly as gate passes. The said identity cards however indicated only their names and the names of the contractors but not the other details like the names of the departments where they worked or their dates of joining etc.

Around $90 \%$ of respondents reported that they were informed by their contractors that they were getting provident fund. But at the same time they complained that they had not been given the numbers of their PF accounts. Hence, they do not know whether their contributions towards the PF are credited in their accounts or otherwise.

It is also observed that in almost majority of cases contract labour gets the overtime, but during the discussion it was found that majority of respondents had no clear idea that what is the proper basis of its calculation. It was observed that payment for the overtime made by the contractor to the contract labour was not according to the rates applicable to the regular workers of the company.

Only about $24 \%$ of the surveyed contract workers reported that they availed this facility of canteen. Majority of these also reported that did not get the facility of the subsidized rates of the food articles served in the canteen, which was available only to the permanent workers. Moreover almost all the respondents agreed that they were provided with safety equipment such as gloves, shoes etc., but they were not in good condition. Gloves were not of good quality; some of the labours even complained that there were injuries in their hands due the bad condition of gloves. Even the safety shoes were observed in a few cases to be in bad condition and without laces. 


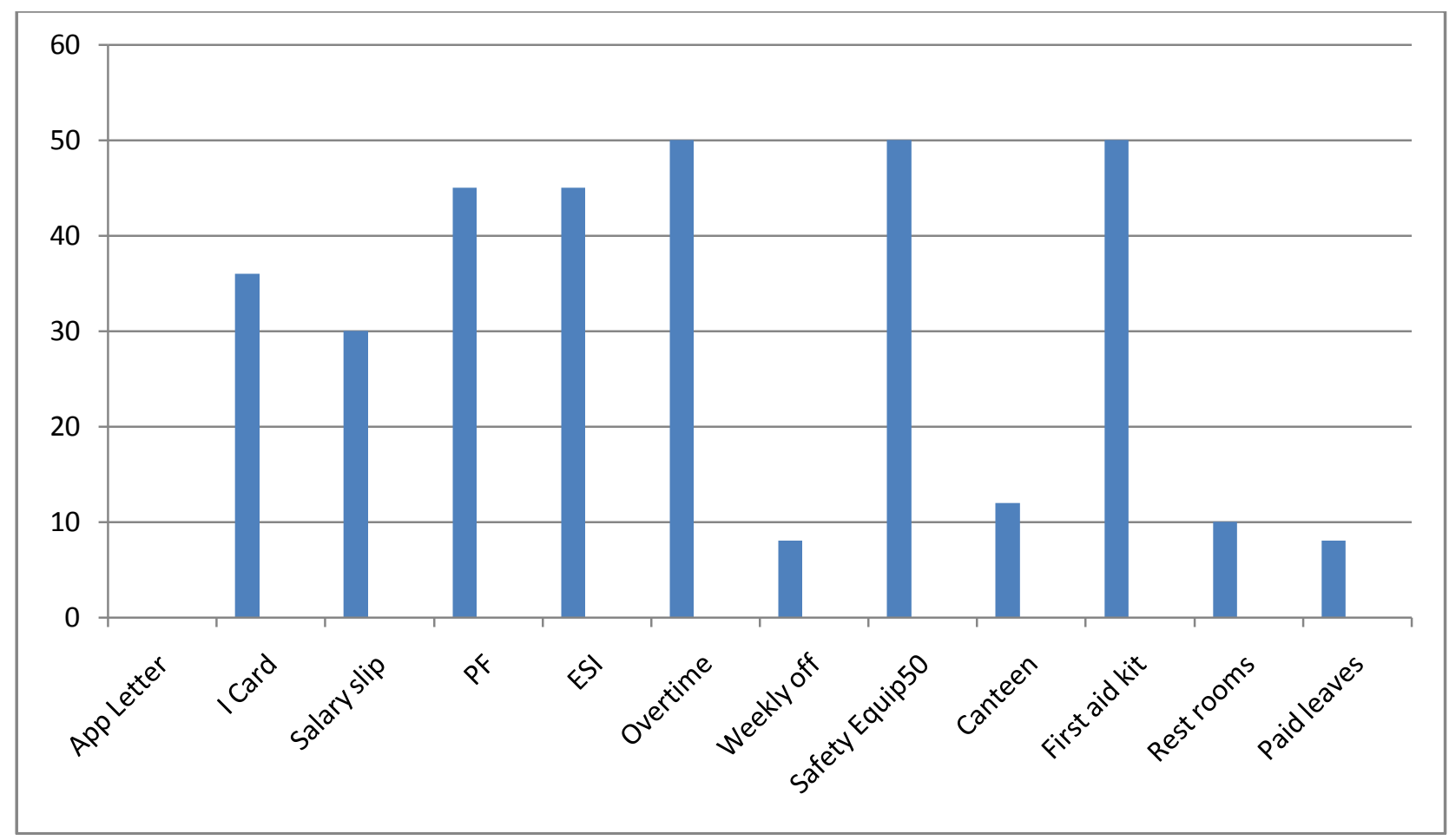

Remunerations for the work:-

During the survey it was found that all the contract labourwas getting full wages on time. The Contractors were paying the prescribed rates of minimum wages.It was seen that the payment of wages to the contract labour surveyed is done by the contractors invariably. Almost $80 \%$ of the respondents reported that no representative of the company is present at the time and place of payment, whereas as per the Rules under the Act, a representative of the Principal Employer must be present.Most of the workers were provided with wages in cash and those having bank accounts their wages are credited into it.

\begin{tabular}{|l|l|l|}
\hline Remunerations for the work & Number & \% \\
\hline Payment of full wages & 45 & 90 \\
\hline Presence of company representative at the time of payment of wages & 8 & 16 \\
\hline Wages credited to account & 25 & 50 \\
\hline
\end{tabular}

Awareness among the contract workers about the Act:-

When the contract workers surveyed were asked, whether they knew anything about this Act, it was found that there was complete ignorance on their part. Not even a single out of the 50 contract workers surveyed stated that they knew something about it. When asked if they knew how to file a complaint in case of any discrepancy, only 2 contract laboursknew regarding the process of filing a complaint in labour court. Infact one of the labor'scases regarding Provident Fund was pending in labour court. Rest of the population hasn't filed any complaint in the labour court and neither had they any knowledge regarding the process to file a complaint. This shows that the reach of the government through this Act is not up to the mark.

\begin{tabular}{|l|l|l|}
\hline Awareness of act & Number & \% \\
\hline Terms and Conditions of Contract & 0 & 0 \\
\hline No. of Workers made a compliant to labour commissioner & 2 & 4 \\
\hline Total & 50 & 100 \\
\hline
\end{tabular}

Focused Discussion in respect of Contractor:-

The discussion was held with 2 contractors. At the outset, they specified that they are fully complying with all the relevant provisions of the Act. . With the apprise in technology they need to maintain all the records online and even the companies/principal employers do not award contracts to the contractor without meeting all the requirements of 
the legal documents needed for the same. Therefore, it is necessary to carry out the contract work in accordance with Act.

During this discussion, the main problem indicated by contractors was to make the contract labour understand regarding the concept of ESIC and Provident Fund. This problem was encountered more with the unskilled labour whose minimum wages was 6330/month. After the ESI and PF deductions, their take home was further reduced, thus creating discontent amongst the labour.

When asked about the availability of contract labor, it was reported by the contractors that there is not much problem to hunt the labour as they are easily available in the region of Garhwal and Himachal. They link up through their local offices in the particular areas to procure contract labour. But there were issues to retain labour in case the labour was poached by some other contractors. In such circumstances the labour was kept on daily basis and even for one day they need to perform all the legal formalities. They had to make their online enrollment for ESI and at the very first day and very first hour of the job the Temporary Insurance Certificate (TIC) is issued to them.

The contractors also discussed that in cases of accidents of labour, quick notification is made to ESIC through online application in ESI Dispensary and worker is referred to panel hospital. The contractors reported that online updating of ESIC has improved the process and has even reduced the paperwork. But they showed their discontent towards maintenance of Provident Fund, which they reported as being complicated with lot of paper work and various forms to be filled on monthly basis.

\section{Conclusion:-}

The Contract Labour (Regulation and Abolition) Act 1970 was enacted with a view to "to regulate the employment of contract labour the certain establishment and to provide its abolition in certain circumstances and for matters connected therewith." However it is observed during the survey that this objective has not been fully achieved.One can clearly conclude through the study that in spite of the fact the nature of work carried out is of permanent character, the labour force employed continues to be temporary. This is done only with a view to deprived the contract workers from claiming the benefits of a permanent worker with the principal employer.Another important factor observed during the study was that, service-breaks to contract workers are given every year, though the contract workers have worked for long periods. This is done for the purpose of avoiding the legal liability that may be arising out of the unremitting service-tenure of contract labour.

After the said breaks, the contract labours are employed afresh. All theseactions are taken in understanding and collaboration with the contractor.The principle of equal pay for the equal work was not observed anywhere. Annual increases in the wages at the year-ends are decided by the contractorsarbitrarily. No criteria appeared to have been applied while determining these

Increases.In terms of facilities provided, there was a huge disparity in the availability of the facilities for the regular permanent workers and the contract workers of these industrial establishments. The contract labour act was enacted with the specific purpose of protecting the contract labour for any exploitation by the contractors and companies. But the ignorance on the part of this illiterate labor about this act and ineffective implementation of the act has led to exploitation of contract labour. Thus it is strongly recommended that government should initiate the knowledge transfer sessions for these contract labour, so as to make them aware of their rights, facilities and liabilities under the contract labour act. Moreover, the government machineries need to work effectivelyto prevent employers from using low cost contract labour as substitute to permanent workers. 


\section{References:-}

1. Contract Labour in India- (labour.nic.in/dglw/session41of ILC.doc)

2. Impact of liberalization on employment in India, Shastri R K, TripathiRavindra and SinghAnushree, International journal of vocational and Technical education volume II (3) PP 33-35July 2010 (www.academicjournals.org/ IJVTE)

3. http://www.ficci.com/spdocument/20189/Industrial-Relations-and-Contract-Labour-in-India

4. http://www.legalserviceindia.com/articles/labour_contract.htm

5. http://articles.economictimes.indiatimes.com/2001-11-05/news/27468286_1_principal-employer-contractlabour-act-labour-union

6. Contract Labour Act in India- A paper with a pragmatic view by Meenakshi Rajeev (IGIDR )Proceedings/ Project report series PP- 062-33 pdf)

7. Meenakshi Rajeev, Series PP-062-33, (2009), Contract Labour Act in India: A Pragmatic View

8. saini, Debi S., The Contract Labour (R\&A) Act 1970 issues and concerns (Estimates), Indian journal of industrial Relations pub dt.7/01/2010.

9. Guest, D. E., Oakley, P., Clinton, M. and Budjanovcanin, A., Free or Precarious? A Comparison of the Attitudes of Workers in Flexible and Traditional Employment Contracts, Human Resource Management Review, 2006, 16(2):107-124. 211

10. Khan, AkhterSobhan, Impact of Globalization on Labour Market and Workers, Challenges and Opportunities:Trade Union Action, Bangladesh Institute of Labour Studies, www.globalnetwork-asia.org, 2005.

11. Poor pay for contract labourers and inequality seen as an important trigger for violence SriramSrinivasan, ET

12. Biggs, D. and Swailes, S., Relations, Commitment, and Satisfaction in Agency Workers and Permanent Workers, Employee Relations, 2007, 28(2): 130-143.

13. Houseman, S. N., Why Employers Use Flexible Staffing Arrangements: Industrial and Labor Relations Review, 2001, 55: 149-170.

14. Kumar, Arun, Labour Law Reforms in India: Some Issues for Consideration, Manpower Journal, 2002, Vol.XXXVII, 4, 39-47. 